\author{
T.I. Mukhambetov \\ Al-Farabi Kazakh National University, Republic of Kazakhstan \\ Mukhambetov.t@gmail.com \\ https://orcid.org/0000-0002-6480-3625,
}

Scopus Author ID: 56028214900

Researcher ID: $A B C-9644-2020$

\title{
Distant motivation against short motivation
}

\begin{abstract}
Object: This article examines the issues of comparative analysis of short, that is, near and long perspectives from the point of view of their impact on employee motivation. Another goal of the article is to develop practical recommendations for the development of Far Distant (Long-term) Motivation in the wage system.

Methods: This study uses quantitative research methods and a trending data collection method. The data were collected through a survey using the same questionnaire in 1994 and in 2010, which made it possible to identify the dynamics of changes in employee motivation. The sample size was 250 respondents.

Findings: The results show that long-term perspectives at work play a huge role for workers. Second, Far Distant Motivation is unfortunately underestimated by employers, as a result of which the potential for increasing employee productivity is not fully exploited.

Conclusions: Research shows that Far Distant Motivation should become an essential element of the motivation system in a company focused on competitiveness. Its presence will increase the competitiveness of the company, the productivity of employees and achieve the integration of personnel into the strategic goals of the company. The widespread practice of Short-Term Motivation based on assessment and remuneration based on short-term results for certain categories of workers has significantly less motivational power than Far Distant Motivation based on assessment of merit and long-term performance results. Therefore, modern companies must build a combination of Short and Far Distant Motivation.

Keywords: Motives of employees, long-term and short-term prospects, Far Distant Motivation, Short Motivation, wage system, wage scale, corporate wage scale, principles of far distant motivation.

\section{Introduction}

The corporate practice of personnel motivation today is largely based on the appraisal of work results, including through personnel assessment using the balanced scorecard, key performance indicators, etc. This causes a short employee motivation.

However, any individuals is focused on the long term of his work. Long-term plans play an important role in the life of any person, which provide him with motivation no less than short stimuli.

In the article, the author, for the first time in the theory of motivation, explores the theoretical aspects and practical issues of implementation long-distance motivation, which he is called Far Distant Motivation (FDM). The author is the founder of this theory, which he has been studying since 1983. The author argues that a new paradigm of motivation based on long-term employee motivation should become a mandatory part of the corporate motivation system. Using the example of researching the motives of employees of different companies, the author showed that incentives extended over long (far) distances and longterm prospects increase overall employee motivation and lead to higher productivity. In its motivational sense, Far Distant Motivation (FDM) acts like a carrot and Short Motivation acts like a stick.
\end{abstract}

\section{Literature Review}

In recent years, the theory of motivation is experiencing a new round of stagnation. This is largely due to changes in the structure of corporate practice requests. Currently, this practice is mostly fascinated by theories of strategic management, production models and operational management (Drake et al., 2007; Franken, 1994). Flexible forms of labor organization and personnel outsourcing are widespread, which is associated with globalization and most technological changes.

In turn, the theory of motivation, unfortunately, can not boast of serious discoveries. For the past 50 years, it has largely relied on well-known substantial and procedural theories of work motivation (Pinder, 2015; Mackay, 2017). 
However, the lack of these theories lies in the fact that they are largely based on the so-called "short" motivation. This means that the stimulation of high productivity is carried out for the specific work and results being carried out (Bernays \& Vickers, 2018; Dweck, 1986). On the contrary, the popularity of encouraging a company's loyalty (loyalty), using long-term incentives in the form of profit in profits and selling shares to employees has decreased significantly. This approach, based on encouraging long-term returns from work and providing employees with long-term perspectives, is called Far Distant Motivation (FDM).

It cannot be said that the corporate practice of motivation today is fully based only on short motivation. To a certain extent, certain elements of long-term motivation are saved and used in practice (McClelland, 1985; Kanfer et al., 2012). Policies aimed at the participation of employees in the profits of companies, the preferential sale of shares (distribution of property); deferred remuneration of labor, premiums to seniority - these elements form the desire of employees and workers to integrate more closely into the company's strategic goals (Gardner \& Shah, 2007; Weiner, 1974; Pritchard \& Ashwood, 2008). The socalled life-long employment are still widespread in Japan.

However, it should be recognized that in practice these elements are increasingly inferior to new trends in the labor market in the form of non-permanent and flexible employment, short-term employment contracts.

\section{Methods}

Work remains the most important value at all times, only slightly changing its level of value at different ages. This was confirmed by a sociological survey, which was conducted by author at intervals of 16 years in Kazakhstan. Different categories of the population acted as questioned people - from university students in Almaty to people aged 65 years. The survey was carried out in Almaty. The number of respondents in both cases was 250 people. The number of unreturned and damaged questionnaires was 21 in 1994, and 18 in 2010. The results of these studies are summarized in the table 1.

Table 1. What is most important in life? (survey in 1994 and 2010)

\begin{tabular}{|c|c|c|c|c|c|c|}
\hline Age, years & 23-27 & $28-35$ & $36-45$ & $46-55$ & $56-65$ & Total, \% \\
\hline \multicolumn{7}{|l|}{ Health } \\
\hline 1994 & & & & $\square$ & $\square$ & $48 \%$ \\
\hline 2010 & & & & $\square$ & $\square$ & $44 \%$ \\
\hline \multicolumn{7}{|l|}{ Work } \\
\hline 1994 & $\square$ & $\square$ & 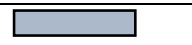 & $\square$ & $\square$ & $64 \%$ \\
\hline 2010 & $\square$ & $\square$ & $\square$ & $\square$ & $\square$ & $71 \%$ \\
\hline \multicolumn{7}{|l|}{ Prosperity } \\
\hline 1994 & $\square$ & $\square$ & $\square$ & $\square$ & $\square$ & $48 \%$ \\
\hline 2010 & $\square$ & $\square$ & प & $\square$ & $\square$ & $69 \%$ \\
\hline \multicolumn{7}{|c|}{ Order and peacein the country } \\
\hline 1994 & & & & $\square$ & $\square$ & $25 \%$ \\
\hline 2010 & & & & $\square$ & $\square$ & $21 \%$ \\
\hline \multicolumn{7}{|l|}{ Family } \\
\hline 1994 & $\square$ & $\square$ & $\square$ & $\square$ & $\square$ & $74 \%$ \\
\hline 2010 & $\square$ & $\square$ & $\square$ & $\square$ & $\square$ & $61 \%$ \\
\hline \multicolumn{7}{|c|}{$\begin{array}{l}\text { Respect forhuman rights } \\
\text { andthe rule of law }\end{array}$} \\
\hline 1994 & & & $\square$ & & & $5 \%$ \\
\hline 2010 & & $\square$ & $\square$ & $\square$ & & $48 \%$ \\
\hline \multicolumn{7}{|l|}{ Close relatives } \\
\hline 1994 & & & $\square$ & ए & $\square$ & $26 \%$ \\
\hline 2010 & & & $\square$ & & $\square$ & $29 \%$ \\
\hline \multicolumn{7}{|c|}{ Recreation \&entertainment } \\
\hline 1994 & & & $\square$ & $\square$ & & $13 \%$ \\
\hline 2010 & $\square$ & $\square$ & $\square$ & $\square$ & $\square$ & $58 \%$ \\
\hline
\end{tabular}


The purpose of the study was to study the changes in the value of different areas of life of Kazakhstan. Since this is not the purpose of this study, we will emphasize the findings regarding labor motivation. As follows from the table:

- Work both in 2010 and 16 years ago remains the most important area of human life.

- The value of work in a person's life changes with age.

Target setting motivation: short and long motivation

Being born, most people, along with basic instincts and reflexes, receive as a gift another very important instinct - the "instinct of success". The human brain is a machine aimed at achieving the objectives.

But with the work the situation is much more complicated. She, as can be seen from the table above, dominates a person for almost his entire life. It largely defines the concept of meaning and happiness in life.

Often, focusing on work during the first half of life, somewhere in the middle of a life's journey, after taking a short break, a person begins to reassess and rethink everything. Often the results of such a rethinking are not comforting: mistakes were made in family life, and the profession chosen was not entirely appropriate (Fiske, 2018). Sometimes this leads to adjustments to the family and work program. Sometimes it all goes on the inertia and the person continues to go with the flow. This means that the fears of change and many other circumstances that have accumulated by this time in parallel with life activity, already begin to dominate and influence the future life. And in that case, the circumstances of life begin to dominate the man, and they determine his fate, but not he himself (Burnett, 2020). The period of such ignorance, the time of "mental blindness" falls on the period of the most active (but often not the most fruitful) part of life - its first half. Millions of people on the planet suddenly begin to realize that they did not achieve goals, or the goalswere erroneous, or that the goals were incorrect. Anyway they received not what they really would like. Possibly they set the wrong goal. Possibly, the goal was false or incorrect, erroneous. Unfortunately, life experience and wisdom grow and accumulate as life postresult, but they are not given in advance. As a result, the real and, unfortunately, life already lived often does not coincide with the plans, goals and ideas that were at the beginning of life (Henry, 2020).

Of course, there is a category of people who have received what they wanted, and who can say that life is successful and they are "lucky", "masters of their life."

There are other categories of people who did not set up large or important firs at all. They live life in simplicity and in harmony in their understanding.

How does this relate to the theory of motivation, to the construction of corporate motivation? In fact, this means that the corporate motivation system should strive to search for the universal inner motives of the majority of employees. These motives should be inherent for most types and groups of people, applicable for most ages.

Along with the well-known classifications of motives for work (development motives, statements, procedural, negative, affiliations, etc.), the division into actual and potential motives should be noted (G D. H. 1889-1959 Cole, 2015).

Motives that take the leading place in practice are constantly updated and indeed have a significant motivational influence on human activity, are actual. Most often, such motives are motivated by fear, for example, the motive for losing one's job, punishment, getting a living wage, etc.

Potential motives are motives not yet used. They can be both individual and characteristic of the majority. However, more often than not, they are not obvious and require identification. They may be less permanent. Satisfying such motives may be more costly for the employer.

Under certain circumstances, potential motives may be satisfied. However, most often due to their complexity in practice they are not given attention.

Of all the signs of motivation, must be mentioned the principles of hierarchy of motives and the principle of individuality of motives (Abernathy, 1996).

The motivational sphere is quite dynamic and therefore the value and influence of individual motifs change. This leads to the fact that the hierarchy of motives is constantly changing. They are relatively stable only for a certain period of time, but most often they change.

But the most important thing is that despite this they remain individual. Even dynamism remains dependent on individuality. For some, motivation may remain unchanged throughout life. Such people can 
work 30-40 years in one workplace. Under the conditions of the industrial revolution and mass production, it was not uncommon. And there are quite a few supporters of such stability now, despite globalization and the increasing dynamism of industry.

The individuality of motivation begins to increase when the number of motives to work for a person grows.

This is the most important thing in motivation. At the same time, each motive has its own driving force.

Sometimes, a single motive can prevail over all and a dissatisfied person leaves work with very attractive conditions. In most cases, however, the more motives are actualized, the stronger the motivation. If you can use additional motives, then the overall level of motivation increases (Omarkhan, Konopyanova, Ishkinina, and Zirkler 2019).

Consequently, the overall level of motivation depends on:

- the number of motives that encourage activity;

- from the driving force of each of these motives.

Based on this pattern, the manager, seeking to increase the motivation of his subordinates, must fulfill three conditions:

1. use (update) the largest possible number of motives;

2. to increase the driving force of each of these motives;

3. activate the most universal motivational factors.

In general, motivation can be defined as the motivation of people to be active, due to the appeal with the help of material or other incentives to his motivational needs and motivational sphere. The motivational sphere of the personality consists of such psychoemotional factors as needs, beliefs, worldview, ideals, inclinations, interests, desires, aspirations, aspirations, fears, moral aspirations, etc.

From this point of view, any manage is the result of the impact on the motivational sphere of a person.

In this case, Far Distant Motivation is the impact on the most delicate strings of the human soul, on the strongest and positive emotions. FDM is accompanied by internal motives of gratitude, sincere impulses and desires. It gives a person a sense of stability and increases his interest in the prosperity of the company. After all, the growth and prosperity of the corporation is associated with its stable future. As a result, it gives a real explosion of productivity and high employee satisfaction. In contrast, short motivation is based on short incentives. If a FDM is comparable to the effects of a carrot, the effects of a Short Motivation are comparable to those of a stick, as it is based on negative emotions and fear, on incentives of coercion.

To create an effective incentive system for employees in a company, it is necessary to find the most optimal variant of the relationship between FDM and Short Motivation.

The following basic principles of an effective FDM scheme can be distinguished:

Direct dependence of earnings on the results. The amount of remuneration depends on the results of the corporation. The employee must make a profit if the business develops successfully (its economic value and profitability increase). If the company does not increase profits, the employee receives a basic wage. At the same time, the employee will suffer losses in earnings if the profitability of the business has become lower (both in terms of lower income and in terms of increased costs).

The dependence of the employee's salary on the length of service in a corporation, but not a simple relationship, but in dynamics and correlated with the results of the growth of its performance indicators.

Clarity and controllability. Effective motivation provides for a certain confidence of the parties and a common interest in a positive result. For an employee, it is important to understand the key parameters by which they will evaluate its effectiveness (Beano, Mauina, Zhansagimova, 2015). The parameters can be: the performance of indicative indicators, balanced indicators, etc. For each company and even more so for each employee, they are individual.

Realistic motivational system and its continuity. This means that when implementing the FDM program for employees, one must remember that once having introduced this system, a corporation will not be able to cancel it. That is why you need to be sure that this system of motivation is necessary at a specific stage of development and that the corporation has sufficient budget for its implementation. 
Focus on employee development. The scheme should be aimed at the continuous development of the employee and the salary should depend on the improvement and professional development of employees.

\section{Results and Discussion}

On the basis of theoretical principles and FDM for the national air-space corporation "Kazakhstan Garysh Sapary" (previously JSC "KAZKOSMOS" ) a corporate wage system was developed.

The tariff part of this system is based on the following principles.

1. Sharing of categories of workers in relation to the main results of activities. All positions / professions of employees of the corporation are distributed to the main and non-core production groups, as well as serving the production. The main categories include specialists whose activities are directly related to space activities. In other words, these are the specialists who are engaged in the preparation, design, creation and operation of space technology and equipment. Non-core groups of workers include those whose activities are not directly related to the implementation of space activities. The category of auxiliary workers mayalso behighlighted.

Table 2 shows the categories of employees of the corporation.

Table 2. Categorization of employees of the corporation "Kazakhstan garish sapary" staff category

\begin{tabular}{|l|l|}
\hline \multicolumn{2}{|c|}{ Senior management, senior managers (members of the Board) } \\
\hline \multirow{5}{*}{ The main production } & Middle management(directorsof departments andtheir deputies) \\
\cline { 2 - 2 } & Lower Level Manager(Head ofdepartmentsand their deputies) \\
\cline { 2 - 2 } & Leading experts(designers) Head. sectors \\
\hline Minorproduction & $\begin{array}{l}\text { Middle managers(directorsof departments andtheir deputies,Advisor } \\
\text { to the Chairman of the Board, the auditor) }\end{array}$ \\
\cline { 2 - 2 } & $\begin{array}{l}\text { Lower Level Manager(Head of Department and deputydirector of } \\
\text { regional branch }\end{array}$ \\
\cline { 2 - 2 } & Leading experts(leadingspecialist, chief specialist, heads of sectors) \\
\cline { 2 - 2 } Service staff & Professionals (engineers, specialist, seniorspecialist) \\
\hline Employees(headof the guard, technician)
\end{tabular}

2. Wage scale (tariff grid). A 16-bit unified tariff wage scale (table 3) was proposed, covering all categories of corporate employees from rank-and-file to a member of the Management Board. For the Chairman of the Management Board, payment is made for an individual contract, however, if the Board of Directors decides on payment under a single tariff scale, he can be graded according to the 16th category.

3. Methods of distribution of work by grade. For the corporation, a Handbook for determining the categories was developed for evaluating the content of work with criteria and descriptions of the complexity of work for each category. In the general case, the distribution of work by grade is carried out by an expert assessment committee based on intuitive and experienced judgments. However, given the lack of experience at the first stage of such work, a specially developed reference guide for job complexity identification was proposed, which allows each job to assign to a specific category on the tariff grade scale.

4. For a more objective assessment of managers' positions, other factors may be taken into account when developing a motivation system. For example, the number of subordinate personnel, the number of managers in subordination, the level of subordination, the number of incoming divisions, the significance of the tasks facing the division, the variety of functions performed and otherscan be taken into account. 


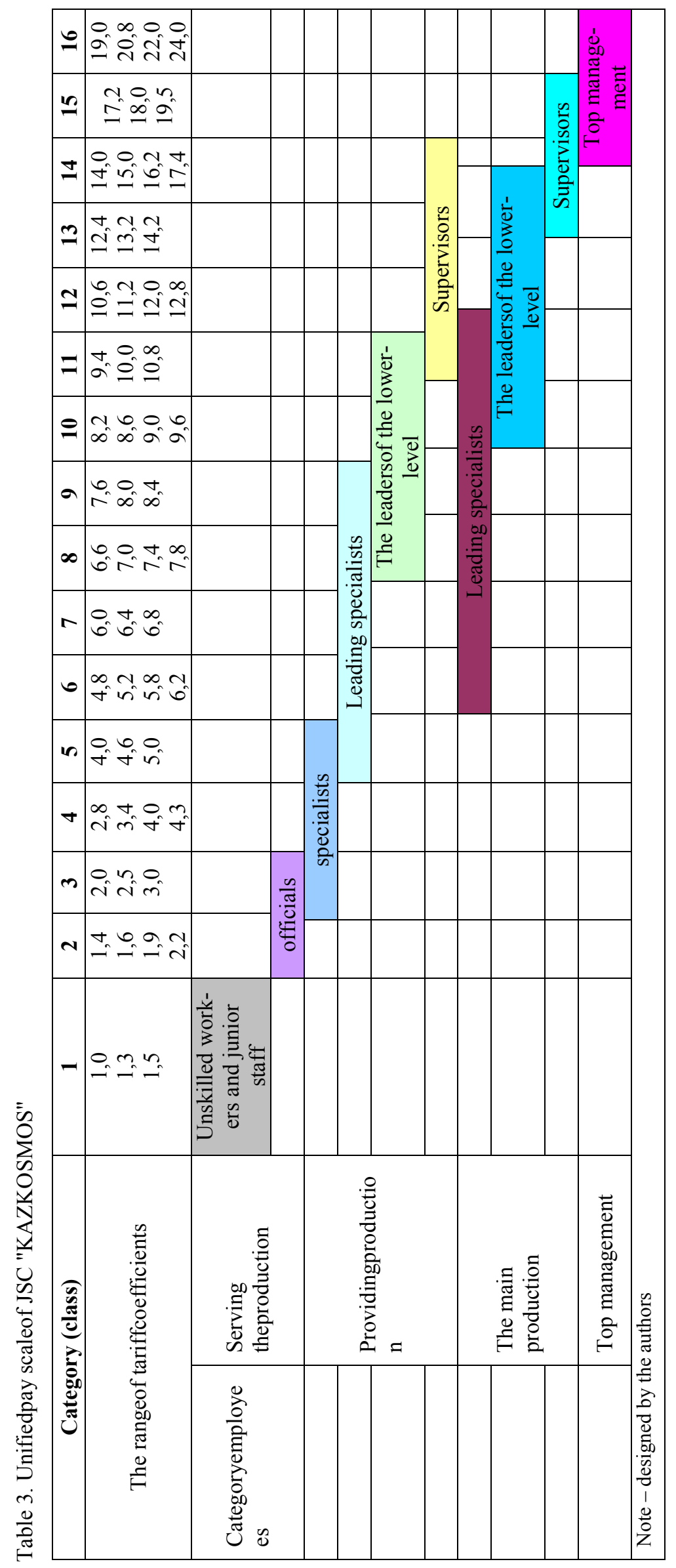


Thus, for example, by the indicator "Significance of the task facing the subdivision" and "Diversity of the functions performed", the periodicity of each task assigned to its subdivision was evaluated and its importance for the subdivision itself was assessed. Naturally, the tasks solved by central accounting department have a higher score than in other departments, due to the "cost" of errors and responsibility of work.

According to the indicator "Variety of Functions", the following were evaluated: analytical function, informational function, control function, methodological guidance, planning function, interaction, production function, search, coordination, etc.

5. In accordance with the reference book the expert assessment group makes an analysis of job descriptions of their corporate value, carried out an assessment of jobs (positions) and grading.

6. The establishment of specific tariff coefficients for employees at specific jobs.

When introducing a corporate wage system specific grades is established:

- By Chairman of the Board for heads of departments and members of the Board;

- By Directors of departments for employees of the department taking into account recommendations of the head of the employee. It is recommended to set tariff coefficients at the minimum forks to create incentives for growth.

Subsequently, based on the results of the annual certification of employees, the adjustment of tariff rates is made downwards or downwards. Quarterly and annual estimates of the employee's work are also used for bonuses.

4. For a more objective assessment of heads when designing incentives can be taken, and other factors: the number of subordinate staff, the number of heads in submission, the level of subordination, the number of incoming units, the task facing the unit (including the frequency and importance of performance), performed by a variety of functions, the adjustment of the number. According to these indicators, the Director of the Finance Department are priced higher than similar corporate development department.

5. In accordance with the guidebook, the expert assessment group analyzes job descriptions, evaluates jobs (positions) and identify specific tariff grade.

6. In accordance with the directory, the expert assessment group analyzes job descriptions, evaluates jobs (positions) and assigns ratings.

6. The establishment of specific tariff ratios for workers at specific workplaces.

When introducing a corporate wage system, specific estimates are established:

- by chairman of the board for heads of departments and board members;

- by department directors for the department employees taking into account the recommendations of the head of the employee. It is recommended that tariff coefficients be set on minimum plugs to create growth incentives.

Subsequently, according to the results of the annual certification of workers, the adjustment of tariff rates is made downwards or downwards. Quarterly and annual employee performance evaluations are also used for bonuses.

\section{Conclusion}

Long-range motivation is an important reserve that is almost never used in modern motivation systems. Among the large number of motivational factors that drive a person, distant goals and motives play a crucial role. The corporate system of Far Distant Motivation is built through linking wages to long-term stable results and the continuous development of the employee in the interests of the company.

Far Distant Motivation most fully meets andhuman needs for a fair assessment of his contribution to the development of the company.

On the basis of a comparative analysis of Short and Far Distant Motivation, three factors can be distinguished that simultaneously both motivate and with the help of which far and short motivation is carried out - this is education, experience and qualifications of the performer. FDM is specifically related to the prospects for professional, qualification, and educational growth throughout the entire working life of an enterprise. The individual himself is interested in this growth, since it meets his needs for self-realization.

A corporate long-term motivation strategy based on the active use of long-term incentives is today the most effective and rational. Short motivation provides support, guiding functionandskills of the performer. Distant motivation is specifically related to the prospects of professional, qualification, educational growth throughout working life at the company. This increase in interest and the individual himself, as it suits his needs for self-actualization. 
The strategy of motivation to work, based on the active use of long-term incentives for action is now the most efficient and effective manner. Short motivation provides supportive, guiding function.

\section{References}

Abernathy, W.B. (1996). The Sin of Wages: Where the Conventional Pay System has Led Us and How. Performance Management Publications.

Bernays, W. and Vickers, N. (2018). Is Motivation a Myth?: Understanding the Process to Master Productivity: Themeworks Production.

Burnett, B. (2020). Designing Your Work Life: How to Thrive and Change and Find Happiness at Work. Knopf.

Drake, A. R., Wong, J. \& Salter, S. B. (2007). Empowerment, Motivation, and Performance: Examining the Impact of Feedback and Incentives on Non-Management Employees. Behavioral Research in Accounting, 19, 71-89.

Dweck, C. S. (1986). Motivational processes affecting learning. American Psychologist, 41(10), 1040-1048. Retrieved from https://doi.org/10.1037/0003-066X.41.10.1040.

Fiske, S.T. (2018). Social Beings: Core Motives in Social Psychology Wiley; 4th edition.

Franken, R. (1994). Human motivation. Pacific Grove, CA: Brooks/Cole.

Gardner, W. and Shah, J. (2007). Handbook of Motivation Science, 1st ed. Durham Univ.: The Guilford Press.

G D. H. 1889-1959 Cole (2015), The Payment of Wages; a Study in Payment by Results Under the Wage-system, Palala Press.

Henry, T. (2020). The Motivation Code: Discover the Hidden Forces That Drive Your Best Work Portfolio. Kindle Edition.

Mackay, A. (2017). Motivation, Ability and Confidence Building in People, 1-st ed., Butterworth-Heinemann.

McClelland, D. C. (1985). How motives, skills, and values determine what people do. American Psychologist, 40(7), 812-825. Retrieved from https://doi.org/10.1037/0003-066X.40.7.812.

Kanfer, R., Chen, G. and Pritchard, R. (2012). Work Motivation: Past, Present and Future (SIOP Organizational Frontiers Series), 1st Ed.: Routledge.

Pinder, C. (2015). Work Motivation in Organizational Behavior, 2-nd ed.: Routledge.

Pritchard, R., and Ashwood, E. (2008). Managing Motivation: A Manager's Guide to Diagnosing and Improving Motivation: Routledge.

Weiner, B. (1974). Achievement motivation and attribution theory. Morristown, N.J., General Learning Press.

Omarkhan,D., Konopyanova, G. Ishkinina, G., Zirkler B. (2019). Main factors analysis of bank staff labor motivation

// Bulletin of the Karaganda University, «Economy» series, 4(96), 275-283

Beano Ya., Mauina G., Zhansagimova A. (2015) Replace the existing socio-economic development and environmental protection // Bulletin of the Karaganda University, «Economy» series, 3(79),98-105

\section{Т.И. Мұхамбетов}

\section{Ұзақ мотивация қарсы қысқа мотивацияға}

\section{Аңдатnа}

Maқ̧cambl: Мақалада қызметкерлердің мотивациясына әсері тұрғысынан қысқа, яғни жақын және алыс перспективаларды салыстырмалы талдау мәселелері қарастырылды. Мақаланың тағы бір мақсаты — жалақы жүйесінде қашықтықтан (ұзақ мерзімді) мотивацияны дамыту бойынша практикалық ұсыныстар әзірлеу.

Әдістері: Зерттеуде сандық зерттеу әдістері және трендтік мәліметтер жинау әдісі қолданылды. Деректер 1994 жылғы және 2010 жылғы сауалнаманы қолдана отырып, өзіндік жұмыс жасау арқылы жинақталды, бұл қызметкерлердің мотивациясының өзгеру динамикасын анықтауға мүмкіндік берді. Іріктеме мөлшері 250 респондентті құрады.

Нәтижелері: Нәтижелер көрсеткендей, ұзақ мерзімді перспективалар жұмысшылар үшін үлкен рөл атқарады. Екіншіден, жұмыс берушілер алыс қашықтықтағы мотивацияны, өкінішке орай, бағаламайды, нәтижесінде жұмысшылардың өнімділігін арттырудың әлеуеті толық пайдаланылмайды.

Kорытынды: Зерттеулер көрсеткендей, қашықтықтағы мотивация бәсекеге қабілеттілікке бағытталған компаниядағы мотивация жүйесінің маңызды элементі болуы керек. Оның болуы компанияның бәсекеге қабілеттілігін, жұмысшылардың еңбек өнімділігін арттырады және персоналдың компанияның стратегиялық мақсаттарына енуіне қол жеткізеді. Жұмысшылардың жекелеген санаттары үшін қысқа мерзімді нәтижелерге негізделген бағалауға және сыйақыға негізделген қысқа мерзімді мотивацияның кең тараған практикасы еңбек сіңірген еңбегін бағалауға және ұзақ мерзімді нәтижелерге негізделген алыс қашықтықтағы мотивацияға қарағанда айтарлықтай аз мотивациялық күшке ие. Сондықтан қазіргі заманғы компаниялар қысқа және алыс қашықтықтағы мотивацияны құруы керек.

Kiлm сөздер: қызметкерлердің мотивтері, ұзақ және қысқа мерзімді перспективалар, қашықтықтағы мотивация, қысқа мотивация, жалақы жүйесі, жалақы шкаласы, корпоративті жалақы шкаласы, алыстағы мотивация принциптері. 


\section{Т.И. Мухамбетов}

\section{Дальняя мотивация против короткой}

\section{Аннотация}

Цель: В статье рассмотрены вопросы сравнительного анализа коротких, то есть ближних и дальних, перспектив с точки зрения их влияния на мотивацию работника. Другой целью статьи является выработка практических рекомендаций по развитию дальней мотивации в системе заработной платы.

Memoдbl: В исследовании использованы количественные методы исследования и трендовый метод сбора информации. Данные были собраны с помощью самостоятельного опроса с использованием одной и той же анкеты в 1994 г. и в 2010 г., что позволило выявить динамику изменения мотивации работников. Объем выборки составил 250 респондентов.

Результаты: Результаты показывают, что дальние перспективы в работе играют для работников огромную роль. Во-вторых, дальняя мотивация работников, к сожалению, недооценивается работодателями, в результате чего потенциал повышения отдачи работников не используется в полной мере.

Bblвoдbl: Исследование показывает, что дальняя мотивация должна стать важнейшим элементом системы мотивации в компании, ориентированной на конкурентоспособность. Ее наличие позволит повысить конкурентоспособность компании, производительность труда работников и достичь интеграции персонала в стратегические цели компании. Широко распространенная практика короткой мотивации на основе оценки и оплаты труда по полученным краткосрочным результатам для отдельных категорий работников обладает значительно меньшей мотивационной мощностью, чем дальняя мотивация на основе оценки заслуг и долгосрочных результатов деятельности. Поэтому современные компании должны выстраивать комбинацию короткой и дальней мотивации сотрудников.

Ключевые слова: мотивы работников, дальние и короткие перспективы, дальняя мотивация, короткая мотивация, система оплаты труда, тарифная сетка, корпоративная тарифная сетка, принципы дальней мотивации.

\section{References}

Abernathy, W.B. The Sin of Wages: Where the Conventional Pay System has Led Us and How. — NY.: Performance Management Publications, 1996. - 188 p.

Bernays, W. and Vickers, N. Is Motivation a Myth?: Understanding the Process to Master Productivity. - W.: Theme works Production, 2018. - 89 p.

Burnett, B. Designing Your Work Life: How to Thrive and Change and Find Happiness at Work. — NY.: Knopf, 2020$186 \mathrm{p}$.

Drake, A.R., Wong, J.\& Salter, S.B. Empowerment, Motivation, and Performance: Examining the Impact of Feedback and Incentives on Non-Management Employees // Behavioral Research in Accounting. — 2007. - № 19, pp. 7189.

Dweck, C.S. (1986). Motivational processes affecting learning // American Psychologist. — 1986. — № 41(10), pp. 1040-1048. - ( https://doi.org/10.1037/0003-066X.41.10.1040).

Fiske, S.T. Social Beings: Core Motives in Social Psychology. — NY.: Wiley, 2018. — 592 p.

Franken, R. Human motivation. Pacific Grove. - CA.: Brooks/Cole, $1994-286$ p.

Gardner, W. and Shah, J. Handbook of Motivation Science, 1st ed. — Durham Univ.: The Guilford Press, 2007. — $342 \mathrm{p}$.

G D. H. 1889-1959 Cole, The Payment of Wages; a Study in Payment by Results Under the Wage-system. - CA.: Palala Press, 2015. - 322 p.

Henry, T. The Motivation Code: Discover the Hidden Forces That Drive Your Best Work Portfolio. - CA.: Kindle Edition, 2020. - 272 p.

Mackay, A. Motivation, Ability and Confidence Building in People, 1-st ed. — NY.: Butterworth-Heinemann, 2017. — $416 \mathrm{p}$.

McClelland, D.C. How motives, skills, and values determine what people do // American Psychologist. — 1985. № 40(7), pp. 812-825. — (https://doi.org/10.1037/0003-066X.40.7.812).

Kanfer, R., Chen, G. and Pritchard, R. Work Motivation: Past, Present and Future (SIOP Organizational Frontiers Series), 1st Ed. - London: Routledge, 2012. — 284 p.

Pinder, C. Work Motivation in Organizational Behavior, 2-nd ed. — London: Routledge, 2015. — 264 p.

Pritchard, R., and Ashwood, E. Managing Motivation: A Manager's Guide to Diagnosing and Improving Motivation. London: Routledge, 2008. - 328 p.

Weiner, B. Achievement motivation and attribution theory. Morristown. — N.J.: General Learning Press, 1974. — $278 \mathrm{p}$.

Omarkhan, D., Konopyanova, G. Ishkinina, G., Zirkler B. Main factors analysis of bank staff labor motivation // Bulletin of the Karaganda University, «Economy» series. — 2019. — № 4(96), pp.275-283.

Beano Ya., Mauina G., Zhansagimova A. Replace the existing socio-economic development and environmental protection // Bulletin of the Karaganda University, «Economy» series. - 2015. — № 3(79), pp. 98-105. 